\title{
Synthesis and UV-shielding Property of Plate-like Potassium Lithium Titanate Coated with Calcia-doped Ceria Nanoparticles
}

\author{
Tsugio SATO, Ahmed Mohamed El-TONI, Shu YIN and Takayuki KUMEI* \\ Institute of Multidisciplinary Research for Advanced Materials, Tohoku University, 1-1, Katahira, 2-chome, Aoba-ku, Sendai $980-8577$ \\ *Research Institute, Fancl Corporation, 12-13, Kamishinano, Totsuka-ku, Yokohama 244-0806
}

\begin{abstract}
In order to attain further performance improvements concerning UV-shielding, the synthesis parameters of plate-like lepidocrocite related potassium lithium titanate were optimized and calcia-doped ceria $\left(\mathrm{Ce}_{0.8} \mathrm{Ca}_{0.2} \mathrm{O}_{1.8}\right)$ nanoparticles were coated on plate-like potassium lithium titanate $\left(K_{0.8} \mathrm{Li}_{0.27} \mathrm{Ti}_{1.73} \mathrm{O}_{4}\right), 10-20 \mu \mathrm{m}$ in diameter via solution processes, where the plate-like titanate was prepared by reacting $\mathrm{K}_{2} \mathrm{CO}_{3}, \mathrm{Li}_{2} \mathrm{CO}_{3}$ and $\mathrm{TiO}_{2} \mathrm{using} \mathrm{KCl}$ flux at $950^{\circ} \mathrm{C}$. After putting plate-like potassium lithium titanate particles in deionized water at $40^{\circ} \mathrm{C}$, appropriate quantities of $3 \mathrm{M} \mathrm{NaOH}$ aqueous solution and $0.8 \mathrm{M} \mathrm{CeCl}_{3}-0.2 \mathrm{M} \mathrm{CaCl}_{2}$ mixed aqueous solution were simultaneously dropped, where the solution was stirred and $\mathrm{pH}$ was kept at 12 throughout the reaction. Then, the desired amount of $2 \mathrm{M} \mathrm{H}_{2} \mathrm{O}_{2}$ solution was added and $\mathrm{pH}$ was also kept at 12 . The slurry was filtrated and washed with water and methanol. The precipitate was fired at $700^{\circ} \mathrm{C}$ for $1 \mathrm{~h}$ to obtain plate-like $\mathrm{K}_{0.8} \mathrm{Li}_{0.27} \mathrm{Ti}_{1.73} \mathrm{O}_{4}$ coated with white $\mathrm{Ce}_{0.8} \mathrm{Ca}_{0.2} \mathrm{O}_{1.8}$ nanoparticles. Such panoscopic assembling successfully improved the comfort of the product when wearing it on the skin without compromising the $\mathrm{UV}$-shielding ability, meanwhile greatly reducing the oxidation catalytic activity.

[Received June 14, 2007; Accepted August 24, 2007]
\end{abstract}

Key-words : Calcia-doped ceria, Plate-like titanate, Composite, UV-shielding ability, Comfort of the product, Oxidation catalytic activity

\section{Introduction}

The damaging effects of UV rays have attracted attention and various UV-shielding materials have been developed in response. Fine powders of titania $\left(\mathrm{TiO}_{2}\right)$, zinc oxide $(\mathrm{ZnO})$ and calcia-doped ceria $\left(\mathrm{Ce}_{1-x} \mathrm{Ca}_{x} \mathrm{O}_{2-x}\right)$ have been commercially used as inorganic sunscreens in personal care products. However, the high refractive indice of titania can make the skin look unnaturally white. In addition, the high photocatalytic activity of $\mathrm{TiO}_{2}$ and $\mathrm{ZnO}$ facilitates the generation of reactive oxygen species, raising safety concerns. ${ }^{1), 2)}$ Ceria possessing a lower refractive index is quite transparent in visible light,,$^{3)}$ but because of its high catalytic ability for the oxidation of organic materials and its yellow color, it was considered to be difficult for use in sunscreen. By doping with $\mathrm{Ca}^{2+}$ possessing lower valence and larger ionic size than those of $\mathrm{Ce}^{4+}$ and clacining at mild temperature around $700^{\circ} \mathrm{C}$, we succeeded in synthesizing novel white nanoparticles of ceria with significantly reduced oxidation catalytic activity and possessing excellent UV absorption capability. ${ }_{4}^{4)-7)}$

Generally, nanoparticles of inorganic materials are not comfortable and do not provide good coverage over the skin because of the agglomeration of the particles. The plate-like particles such as mica, talc, etc. are often used to improve the comfort and covering ability of inorganic UV shielding materials. The mixing with mica and talc, however, generally results in a decrease in the UV-shielding performance since mica and talc does not possess UV-absorption ability. In order to improve the feeling of wearing calcia-doped ceria without loss of UV-shielding performance, we tried to use plate-like lepidocrocite type potassium lithium titanate possessing UVshielding ability in stead of mica and talc. Lepidocrocite type potassium lithium titanate is an n-type semiconductor possessing band gap energy of about $3.5 \mathrm{eV}^{8)}$ and consists of sheets arranged parallel to each other. Upon coupling calcia-doped ceria nanoparticles with plate-like materials, two advantages can be expected. First, a softer and nicer feeling upon application will be acquired for calcia-doped ceria nanoparticles. Second, better distribution with improved coverage ability of calcia-doped ceria nanoparticles on the skin, will inevitably enhance the UV-shielding ability of $\mathrm{CaO}$-doped ceria. In this work, the synthesis parameters of plate-like lepidocrocite related potassium lithium titanate were optimized and platelike potassium lithium titanate coated with calcia-doped ceria nanoparticles was prepared by a solution chemical method and characterized the photo-chemical properties of the product.

\section{Experimental procedure}

Synthesis of plate-like lepidocrocite type potassium lithium titanate: Plate-like lepidocrocite type potassium lithium titanate was prepared by a flux method ${ }^{9)}$ as follows. The powders of $\mathrm{K}_{2} \mathrm{CO}_{3}, \mathrm{Li}_{2} \mathrm{CO}_{3}$ and $\mathrm{TiO}_{2}$ (anatase form) were mixed intimately at a molar ratio of $3: 1: 13$ (nominal composition: $\mathrm{K}_{0.8} \mathrm{Li}_{0.266} \mathrm{Ti}_{1.734} \mathrm{O}_{4}$ ) and the mixture was placed in a Pt crucible and heated at $800^{\circ} \mathrm{C}$ for $30 \mathrm{~min}$ to be decarbonated. After cooling, the raw material was ground along with a desired amount of flux salt, put in a Pt crucible and then heated up to a desired temperature at a heating rate of $200^{\circ} \mathrm{C} \mathrm{h}^{-1}$ then the temperature was fixed at that temperature for $120 \mathrm{~min}$. After that the temperature was decreased to $800^{\circ} \mathrm{C}$ at a rate of $50^{\circ} \mathrm{C} \mathrm{h}^{-1}$ and then to room temperature naturally. To clarify the optimum reaction conditions, the morphologies of the particles prepared with various flux compounds were investigated. All experimental products were washed with hot water to remove the flux and dried at $80^{\circ} \mathrm{C}$.

Synthesis of plate-like potassium lithium titanate coated with calcia-doped ceria nanoparticles: Plate-like potassium lithium titanate coated with calcia-doped ceria nanoparticles was synthesized using the solution chemical route as follows. ${ }^{4)-7)}$ After putting potassium lithium titanate particles in deionized water at $40^{\circ} \mathrm{C}$, appropriate quantities of $3 \mathrm{M} \mathrm{NaOH}$ aqueous solution and $0.8 \mathrm{M} \mathrm{CeCl}_{3}-0.2 \mathrm{M} \mathrm{CaCl}_{2}$ mixed aqueous solution were simultaneously dropped, where the solution was stirred and $\mathrm{pH}$ was kept at 12 throughout the reaction. Then, the desired amount of $2 \mathrm{M} \mathrm{H}_{2} \mathrm{O}_{2}$ solution was added while $\mathrm{pH}$ was also kept at 12 . The chemical reactions can be expressed by Eqs. (1) and (2). 


$$
\begin{aligned}
& 0.8 \mathrm{CeCl}_{3}+0.2 \mathrm{CaCl}_{2}+2.8 \mathrm{NaOH} \\
& \rightarrow \mathrm{Ce}_{0.8} \mathrm{Ca}_{0.2}(\mathrm{OH})_{2.8}+2.8 \mathrm{NaCl} \\
& \mathrm{Ce}_{0.8} \mathrm{Ca}_{0.2}(\mathrm{OH})_{2.8}+0.4 \mathrm{H}_{2} \mathrm{O}_{2} \\
& \rightarrow \mathrm{Ce}_{0.8} \mathrm{Ca}_{0.2} \mathrm{O}_{1.8}+1.8 \mathrm{H}_{2} \mathrm{O}
\end{aligned}
$$

The slurry was filtrated and washed with water and methanol. The precipitate was fired at $700^{\circ} \mathrm{C}$ for $1 \mathrm{~h}$ to obtain potassium lithium titanate coated with white $\mathrm{Ce}_{0.8} \mathrm{Ca}_{0.2} \mathrm{O}_{1.8}$ nanoparticles. Characterizations: The crystalline phase was determined by $\mathrm{X}$-ray powder diffraction analysis (SHIMADZU, XD-01) with $\mathrm{CuK} \alpha$ radiation. The catalytic ability for oxidation of organic material was determined by a conductometric determination method (Rancimat method) ${ }^{10)}$ using cosmetic grade castor oil as an oxidized material. The sample powder $(1 \mathrm{~g})$ was mixed with castor oil $(10 \mathrm{~g})$ and set at $120^{\circ} \mathrm{C}$ with bubbling $500 \mathrm{~cm}^{3} \mathrm{~min}^{-1}$ of air, where the air was introduced into deionized water. The catalytic ability was determined by measuring the increase in the electric conductivity of deionized water by trapping the volatile molecules coming from the oxidation of castor oil on heating. The UV-shielding ability of samples were evaluated by measuring the transmittance spectra of thin films uniformly dispersing sample powders with an UV-Vis spectrophotometer (SHIMADZU, UV-2450), where $2 \mathrm{~g}$ of the sample, $4 \mathrm{~g}$ of nitrocellulose of industrial grade, $10 \mathrm{~g}$ of ethyl acetate and $9 \mathrm{~g}$ of butyl acetate were mixed uniformly using a paint shaker and $100 \mathrm{~g}$ zirconia ball, $2.7 \mathrm{~mm}$ in diameter for $40 \mathrm{~h}$. The dispersion mixture was applied onto a quartz glass plate with an applicator. The thickness of the film was $12.5 \mu \mathrm{m}$. The particle morphology was evaluated by a transmission electron microscope (JEM-2000 EX). A scanning electron microscope (Hitachi, S 4100) was used to study the surface morphology. XPS spectra were measured at room temperature by X-ray electron spectrometer (Perkin Elmer, PHI 5600) and $\mathrm{O}_{1 \mathrm{~s}}$ spectra were collected for samples. The low-level luminous intensity of chemiluminescence of singlet oxygen $\left({ }^{1} \mathrm{O}_{2}\right)$ was directly measured with a multichemiluminescence spectrometer (Tohoku Electric Ind., MLA-GOLDS$\mathrm{S})$. Approximately $1 \mathrm{~g}$ of the sample powder was placed into a stainless steel cell $(50 \mathrm{~mm}$ in diameter and $10 \mathrm{~mm}$ in depth) covered with a quartz cell. The test sample was irradiated in air with UV rays of $254 \mathrm{~nm}$ for $5 \mathrm{~s}$ at room temperature. Chemiluminescence intensity was measured $5 \mathrm{~s}$ later for $100 \mathrm{~s}$, where a red filter which transmits only light at wavelengths greater than $600 \mathrm{~nm}$ was placed between the cuvette and the photomultiplier to cut off the emission attributed to carbonyl compounds. The feeling of wearing the sample powder on the skin was evaluated using a friction tester (Katotech, KES-SE) which employs a piano wire as a friction element and artificial leather (Idemitsu Technofine Co., Sapurare ${ }^{\circledR}$ ), where the sample powder was applied on the artificial leather using a make-up brush.

\section{Result and discussion}

3.1 Synthesis of micaceous lepidocrocite type potassium lithium titanate

The powder X-ray diffraction patterns of the samples formed using $\mathrm{K}_{2} \mathrm{MoO}_{4}$ flux at different nominal Li contents $\left(\mathrm{K}_{3 x} \mathrm{Ti}_{2-x} \mathrm{LixO}_{4}\right)$ are shown in Fig. 1. All the diffraction peaks of the sample of $x=0.27$ were attributed to lepidocrociterelated titanate. ${ }^{8)}$ Conversely, at Li content $x=0.19$ and $x=$ 0.36 , potassium tetratitanate $\left(\mathrm{K}_{2} \mathrm{Ti}_{4} \mathrm{O}_{9}\right)$ and $\mathrm{Li}_{2} \mathrm{TiO}_{3}$ appeared in addition to lepidocrocite-related titanate.

SEM micrographs of $\mathrm{K}_{3 x} \mathrm{Ti}_{2-x} \mathrm{Li}_{\mathrm{x}} \mathrm{O}_{4}$ with the $\mathrm{Li}$ contents, $x=0.19,0.27,0.36$ and 0.52, are shown in Fig. 2. The sample of $x=0.27$ consisted of the plate-like particles, but needle-like

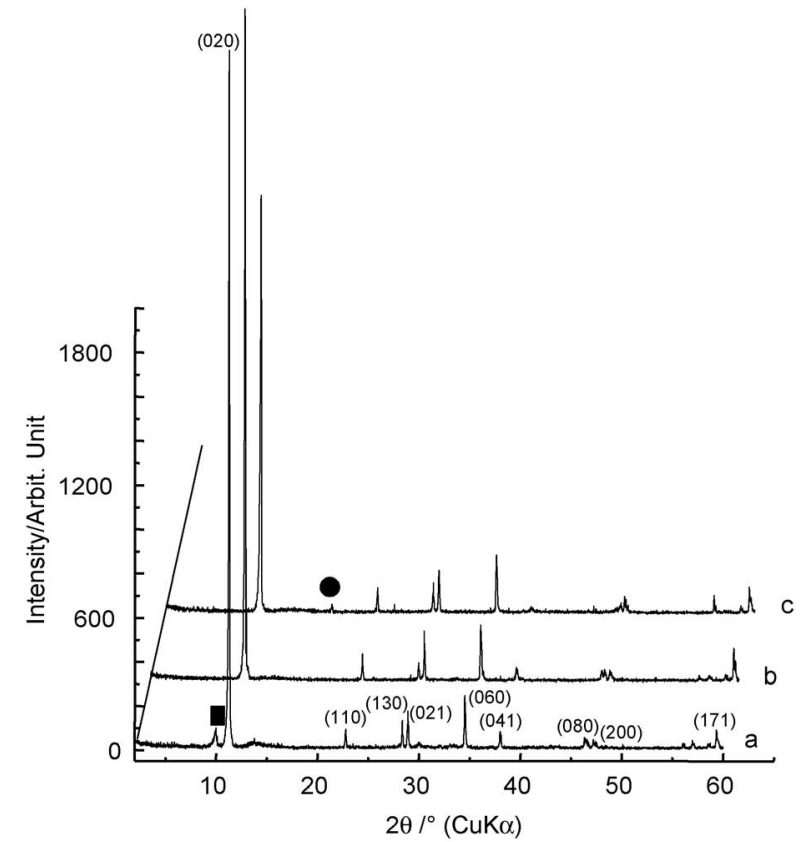

Fig. 1. Powder X-ray diffraction patterns of the samples formed with various lithium contents and a raw material to $\mathrm{K}_{2} \mathrm{MoO}_{4}$ flux weight ratio of $50: 50$ at $1000^{\circ} \mathrm{C}$ for $120 \mathrm{~min}$ and a cooling rate of $50^{\circ} \mathrm{C} \mathrm{h}^{-1}$. Nominal Li content $\mathrm{x}$ in $\mathrm{K}_{3 x} \mathrm{Ti}_{2-x} \mathrm{Li}_{x} \mathrm{O}_{4}$ : (a) 0.19 , (b) 0.27 , (c) 0.36. : $\mathrm{Li}_{2} \mathrm{TiO}_{3}, \square: \mathrm{K}_{2} \mathrm{Ti}_{4} \mathrm{O}_{9},(h k l)$ : Mirror index of lepidocrocite-related titanate.
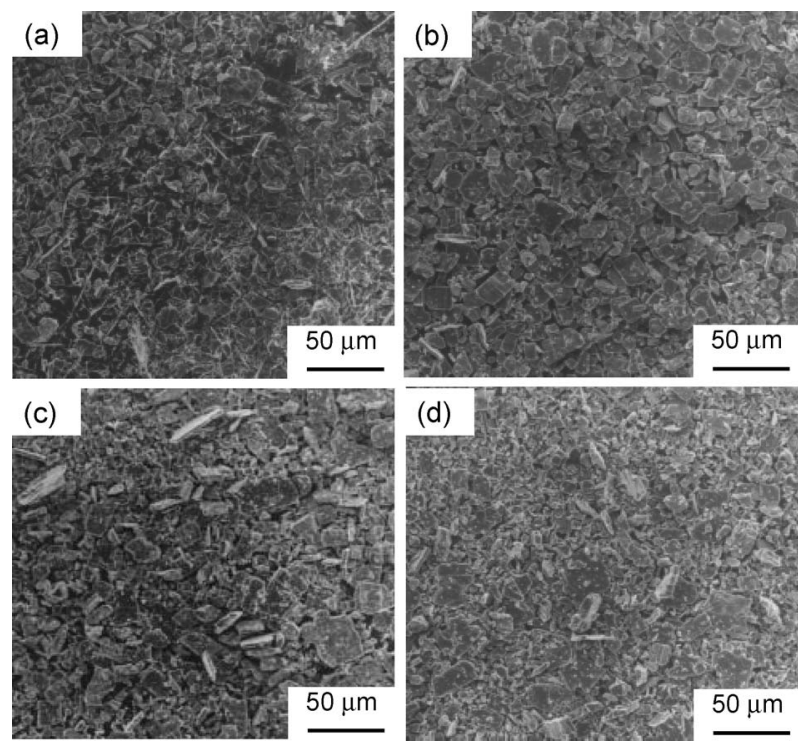

Fig. 2. Scanning electron micrographs of the samples formed with a raw material to a flux weight ratio of $50: 50$ at $1000^{\circ} \mathrm{C}$ for 120 min and a cooling rate of $50^{\circ} \mathrm{C} \mathrm{h}^{-1}$ with the nominal Li content $x$ in $\mathrm{K}_{3 x} \mathrm{Ti}_{2-x} \mathrm{Li}_{x} \mathrm{O}_{4}$ : (a) 0.19 , (b) 0.27 , (c) 0.36 and (d) 0.52 .

particles and irregular shaped particles appeared along with plate-like particles in the samples of $x=0.19$ and $0.36-0.52$, respectively. Therefore, plate-like particles, needle-like particles and irregular shape particles were identified as lepidochrocite-related titanate, $\mathrm{K}_{2} \mathrm{Ti}_{4} \mathrm{O}_{9}$ and $\mathrm{Li}_{2} \mathrm{TiO}_{3}$, respectively, indicating that single phase lepidocrocite-related titanate is formed with a limited amount of lithium content. Therefore, 

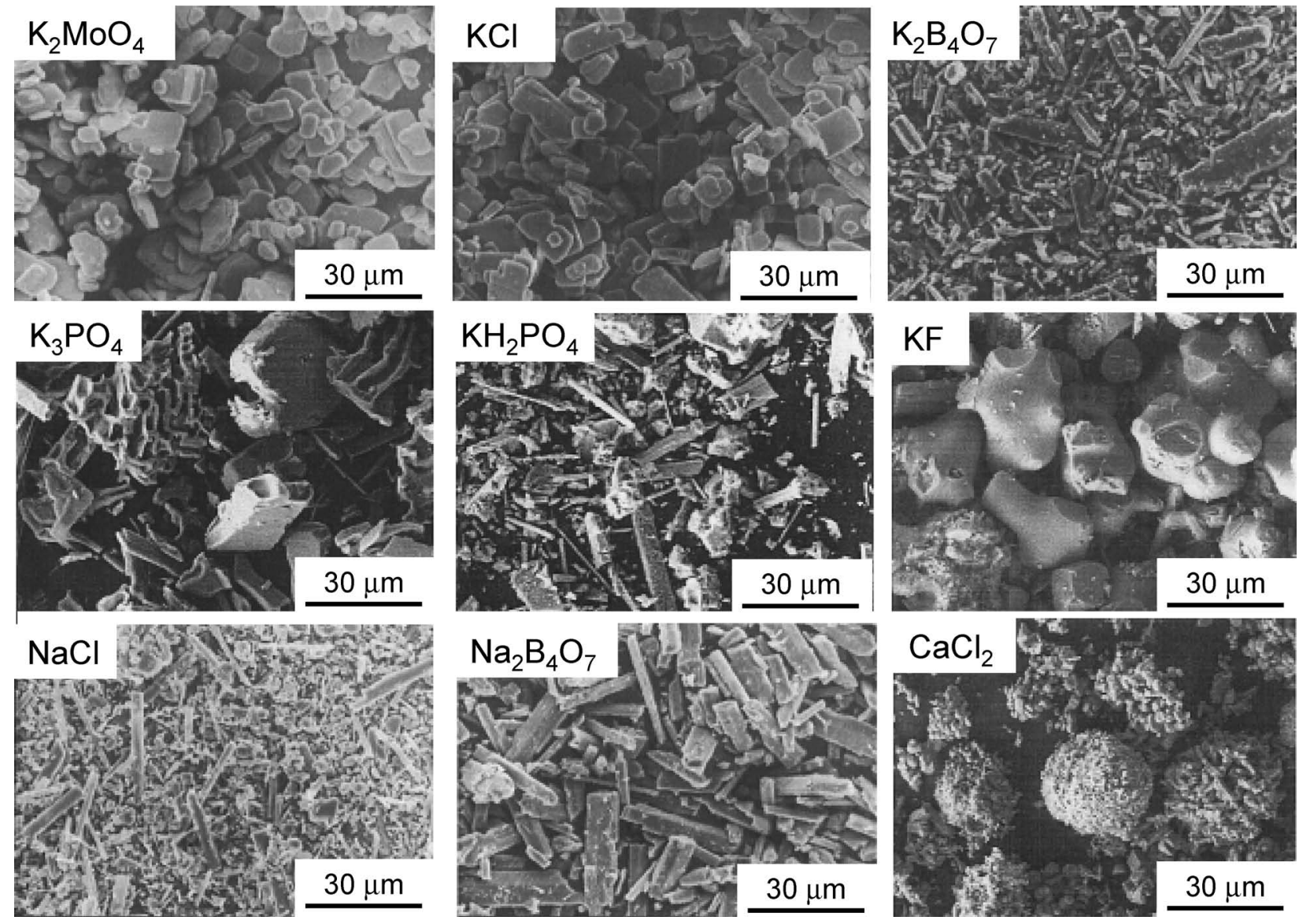

Fig. 3. Scanning electron micrographs of the samples formed using various flux compounds with a raw material to a flux weight ratio of 50:50 at $950^{\circ} \mathrm{C}$ for 120 min and a cooling rate of $50^{\circ} \mathrm{C} \mathrm{h}^{-1}$ with the nominal Li content $x$ in $\mathrm{K}_{3 x} \mathrm{Ti}_{2-x} \mathrm{Li}_{x} \mathrm{O}_{4}$ of 0.27 .

the single phase sample with the chemical composition of $\mathrm{K}_{0.81} \mathrm{Li}_{0.27} \mathrm{Ti}_{1.73} \mathrm{O}_{4}$ was used for further experiment.

Scanning electron micrographs of the samples formed using various flux salts with a raw material to a flux weight ratio of $50: 50$ at $1000^{\circ} \mathrm{C}$ for $120 \mathrm{~min}$ and a cooling rate of $50^{\circ} \mathrm{C} \mathrm{h}^{-1}$ with the nominal Li content $x$ in $\mathrm{K}_{3 x} \mathrm{Ti}_{2-x} \mathrm{Li}_{x} \mathrm{O}_{4}$ of 0.27 are shown in Fig. 3. The morphology of the product greatly changed depending on the kind of flux salt. It is seen that the sample prepared using $\mathrm{KCl}$ flux showed almost identical platelike morphology to that prepared using $\mathrm{K}_{2} \mathrm{MoO}_{4}$ flux.

The effects of $\mathrm{KCl}$ flux content and temperature on the morphology of $\mathrm{K}_{0.81} \mathrm{Ti}_{1.73} \mathrm{Li}_{0.27} \mathrm{O}_{4}$ are shown in Fig. 4. The product at $750^{\circ} \mathrm{C}$ consisted of spherical agglomerated particles of $20-30 \mu \mathrm{m}$ in diameter. Conversely, the products above $850^{\circ} \mathrm{C}$ consisted of plate-like particles, where the particle size increased with increasing reaction temperature. The plate-like particles of $10-30 \mu \mathrm{m}$ in diameter which is similar to that of cosmetic grade mica could be obtained around $950^{\circ} \mathrm{C}$. The particle size of the product did not change so much by changing the $\mathrm{KCl}$ flux content from $25-50$ mass $\%$ at $950^{\circ} \mathrm{C}$.

3.2 Preparation and photochemical properties of $\mathrm{K}_{0.81} \mathrm{Li}_{0.27} \mathrm{Ti}_{1.73} \mathrm{O}_{4}$ coated with $\mathrm{Ce}_{0.8} \mathrm{Ca}_{0.2} \mathrm{O}_{1.8}$

Scanning electron micrographs of $\mathrm{K}_{0.81} \mathrm{Li}_{0.27} \mathrm{Ti}_{1.73} \mathrm{O}_{4}$ coated with $\mathrm{Ce}_{0.8} \mathrm{Ca}_{0.2} \mathrm{O}_{1.8}$ nanoparticles as prepared is shown in Fig. $5(a) . \quad \mathrm{K}_{0.81} \mathrm{Li}_{0.27} \mathrm{Ti}_{1.73} \mathrm{O}_{4}$ possessed micaceous structure with a diameter of $15-20 \mu \mathrm{m}$. It can be observed that $\mathrm{Ce}_{0.8} \mathrm{Ca}_{0.2} \mathrm{O}_{1.8}$ nanoparticles precipitated on the surface of plate-like $\mathrm{K}_{0.81} \mathrm{Li}_{0.27} \mathrm{Ti}_{1.73} \mathrm{O}_{4}$ particles, but irregularly shaped agglomerates of $\mathrm{Ce}_{0.8} \mathrm{Ca}_{0.2} \mathrm{O}_{1.8}$ also appeared. By dispersion in water and decantation, most irregularly shaped agglomerates could be removed as shown in Fig. 5(b).

A scanning electron micrograph with high magnification (Fig. 6(a)) shows that the surface of the $\mathrm{K}_{0.81} \mathrm{Li}_{0.27} \mathrm{Ti}_{1.73} \mathrm{O}_{4}$ particle is covered with $\mathrm{Ce}_{0.8} \mathrm{Ca}_{0.2} \mathrm{O}_{1.8}$ nanoparticles. The diameter of $\mathrm{Ce}_{0.8} \mathrm{Ca}_{0.2} \mathrm{O}_{1.8}$ particles was ca. $15 \mathrm{~nm}$ (Fig. 6(b)).

Figure 7 shows the entire XPS spectra and XPS $\mathrm{O}_{1 \mathrm{~s}}$ core level spectra of (a) $\mathrm{K}_{0.81} \mathrm{Li}_{0.27} \mathrm{Ti}_{1.73} \mathrm{O}_{4}$, (b) $\mathrm{Ce}_{0.8} \mathrm{Ca}_{0.2} \mathrm{O}_{1.8}$ and (c) $\mathrm{K}_{0.81} \mathrm{Li}_{0.27} \mathrm{Ti}_{1.73} \mathrm{O}_{4}$ coated with $\mathrm{Ce}_{0.8} \mathrm{Ca}_{0.2} \mathrm{O}_{1.8}$. The XPS spectrum of $\mathrm{K}_{0.81} \mathrm{Li}_{0.27} \mathrm{Ti}_{1.73} \mathrm{O}_{4}$ coated with $\mathrm{Ce}_{0.8} \mathrm{Ca}_{0.2} \mathrm{O}_{1.8}$ was almost identical to that of $\mathrm{Ce}_{0.8} \mathrm{Ca}_{0.2} \mathrm{O}_{1.8}$, indicating no peak corresponding to $\mathrm{K}_{0.81} \mathrm{Li}_{0.27} \mathrm{Ti}_{1.73} \mathrm{O}_{4}$. Since XPS is a rather surface sensitive technique, i.e., the sampling depth is less than ca. $4 \mathrm{~nm}$, depending on electro kinetic energy, the spectrum reveals the chemical state of the outer layer of the particle. Since the XPS spectrum of $\mathrm{K}_{0.81} \mathrm{Li}_{0.27} \mathrm{Ti}_{1.73} \mathrm{O}_{4}$ coated with $\mathrm{Ce}_{0.8} \mathrm{Ca}_{0.2} \mathrm{O}_{1.8}$ (Fig. 7(A) c) showed only the peaks characteristic of $\mathrm{Ce}_{0.8} \mathrm{Ca}_{0.2} \mathrm{O}_{1.8}$ at 888.5 and $882.3 \mathrm{eV}$ which corresponded to $\mathrm{Ce}^{4+}$ and at $346.4 \mathrm{eV}$ assigned to $\mathrm{Ca}_{2 \mathrm{p}}$, it was confirmed that $\mathrm{K}_{0.81} \mathrm{Li}_{0.27} \mathrm{Ti}_{1.73} \mathrm{O}_{4}$ was entirely coated with $\mathrm{Ce}_{0.8} \mathrm{Ca}_{0.2} \mathrm{O}_{1.8}$ particles. For $\mathrm{Ce}_{0.8} \mathrm{Ca}_{0.2} \mathrm{O}_{1.8}$ (Fig. 7(B)b), a large peak at $528.5 \mathrm{eV}$ was attributed to lattice oxygen ion, and a smaller one at $531 \mathrm{eV}$ was attributed to adsorbed oxygen. The peak of lattice oxygen of $\mathrm{K}_{0.81} \mathrm{Li}_{0.27} \mathrm{Ti}_{1.73} \mathrm{O}_{4}$ appeared at $529.5 \mathrm{eV}$ (Fig. 7(B)a). In a previous paper ${ }^{11}$ it was reported that $\mathrm{O}_{1 \mathrm{~s}}$ spectra of $\mathrm{Ce}_{0.8} \mathrm{Ca}_{0.2} \mathrm{O}_{1.8}$ shifted by coating with amorphous silica by forming a chemical bond of $\mathrm{Ce}-\mathrm{O}-\mathrm{Si}$, but $\mathrm{O}_{1 \mathrm{~s}}$ spectra of $\mathrm{K}_{0.81} \mathrm{Li}_{0.27} \mathrm{Ti}_{1.73} \mathrm{O}_{4}$ coated with $\mathrm{Ce}_{0.8} \mathrm{Ca}_{0.2} \mathrm{O}_{1.8}$ showed no noticeable chemical shift, suggesting 


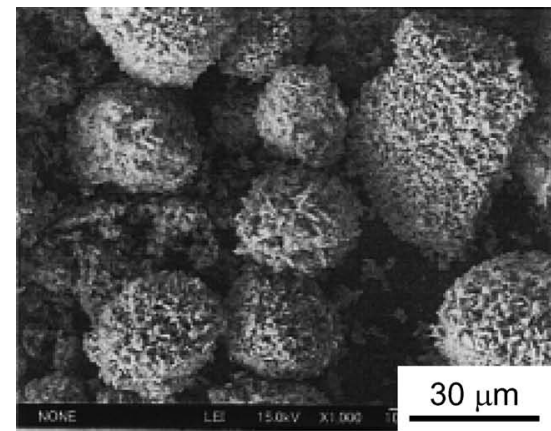

$\mathrm{KCl} 50$ mass $\%, 750^{\circ} \mathrm{C}, 2 \mathrm{~h}$

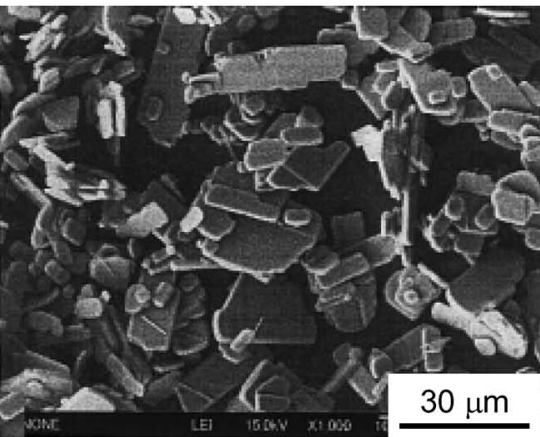

$\mathrm{KCl} 40$ mass $\%, 950^{\circ} \mathrm{C}, 2 \mathrm{~h}$

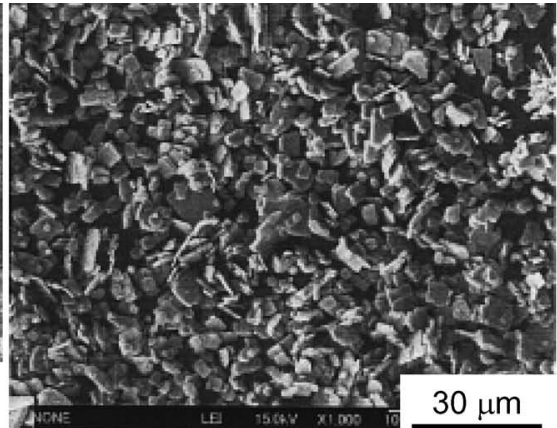

$\mathrm{KCl} 50$ mass $\%, 850^{\circ} \mathrm{C}, 2 \mathrm{~h}$

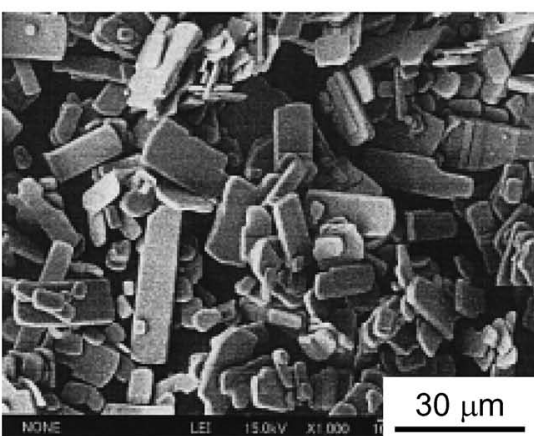

$\mathrm{KCl} 50$ mass $\%, 950^{\circ} \mathrm{C}, 2 \mathrm{~h}$

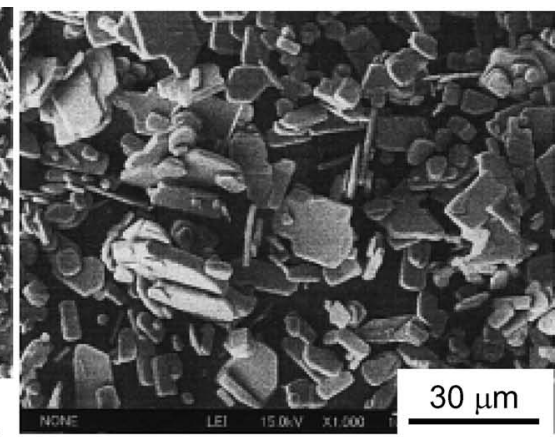

$\mathrm{KCl} 25$ mass $\%, 950^{\circ} \mathrm{C}, 2 \mathrm{~h}$

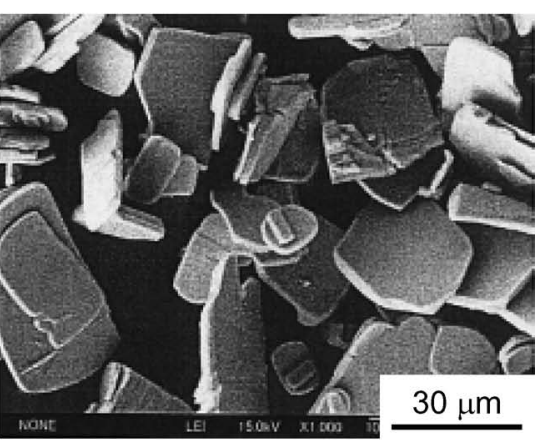

$\mathrm{KCl} 50$ mass $\%, 1050^{\circ} \mathrm{C}, 2 \mathrm{~h}$

Fig. 4. Effect of $\mathrm{KCl}$ flux content and temperature on the morphology of $\mathrm{K}_{0.81} \mathrm{Ti}_{1.73} \mathrm{Li}_{0.27} \mathrm{O}_{4}$.

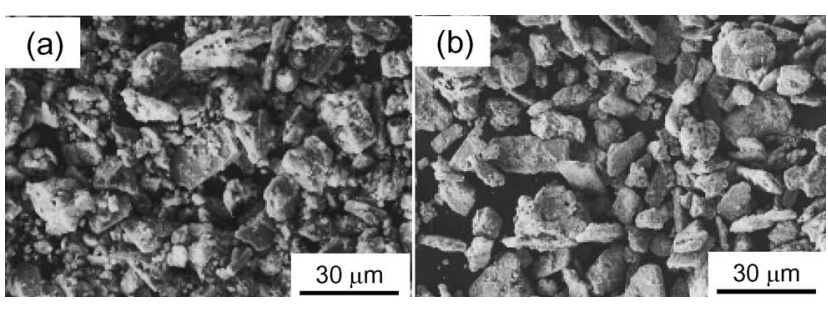

Fig. 5. Scanning electron micrographs of (a) $\mathrm{K}_{0.81} \mathrm{Li}_{0.27} \mathrm{Ti}_{1.73} \mathrm{O}_{4}$ coated with 70 mass $\% \mathrm{Ce}_{0.8} \mathrm{Ca}_{0.2} \mathrm{O}_{1.8}$. (a) as-prepared, (b) dispersed in water followed by decantation.
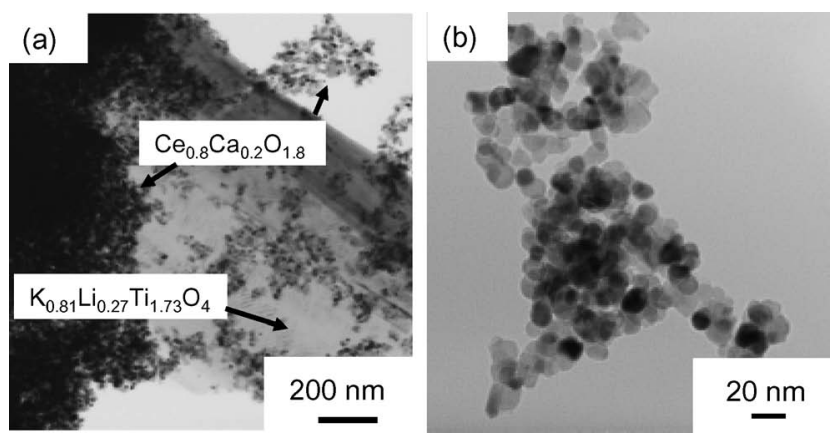

Fig. 6. (a) Scanning electron micrograph of $\mathrm{K}_{0.81} \mathrm{Li}_{0.27} \mathrm{Ti}_{1.73} \mathrm{O}_{4}$ particle coated with $\mathrm{Ce}_{0.8} \mathrm{Ca}_{0.2} \mathrm{O}_{1.8}$ nanoparticles and (b) transmission electron micrograph of $\mathrm{Ce}_{0.8} \mathrm{Ca}_{0.2} \mathrm{O}_{1.8}$ particles on $\mathrm{K}_{0.81} \mathrm{Li}_{0.27} \mathrm{Ti}_{1.73} \mathrm{O}_{4}$ particle.

that $\mathrm{Ce}_{0.8} \mathrm{Ca}_{0.2} \mathrm{O}_{1.8}$ physically covers the surface of $\mathrm{K}_{0.81} \mathrm{Li}_{0.27}$ $\mathrm{Ti}_{1.73} \mathrm{O}_{4}$ and no chemical linkage was developed at the inter- face.

In order to evaluate the feeling of applying sample powder to skin, the kinetic friction coefficients of the artificial leather before and after applying various sample powders on were determined using a friction tester. The results are shown in Fig. 8. Plate-like $\mathrm{K}_{0.81} \mathrm{Li}_{0.27} \mathrm{Ti}_{1.73} \mathrm{O}_{4}$ showed low kinetic friction coefficient similar to BN (Mizushima Ferroally Co., SHP-4) which is known as a solid lubricant. Conversely, $\mathrm{Ce}_{0.8} \mathrm{Ca}_{0.2} \mathrm{O}_{1.8}$ nanoparticles showed a higher kinetic friction coefficient similar to that of cosmetic grade titania nanoparticles (Ishihara Sangyo Co., TTO-55A). As expected, the kintetic friction coefficient of $\mathrm{K}_{0.8} \mathrm{Li}_{0.27} \mathrm{Ti}_{1.73} \mathrm{O}_{4}$ coated with $\mathrm{Ce}_{0.8} \mathrm{Ca}_{0.2} \mathrm{O}_{1.8}$ was much lower that that of $\mathrm{Ce}_{0.8} \mathrm{Ca}_{0.2} \mathrm{O}_{1.8}$ and was almost identical to that of cosmetic grade talc coated with 50 mass $\%$ tiania (Catalysts \& Chemicals Ind. Co., Coverleaf PC-2055T), indicating that plate-like $\mathrm{K}_{0.8} \mathrm{Li}_{0.27} \mathrm{Ti}_{1.73} \mathrm{O}_{4}$ is useful as a means to improve the comfort of applying $\mathrm{Ce}_{0.8} \mathrm{Ca}_{0.2} \mathrm{O}_{1.8}$ nanoparticles on the skin.

The UV shielding ability of the sample was evaluated by measuring the UV-Vis transmittance spectrum of the thin film uniformly dispersing sample powder. As shown in Fig. 9, the onsets of absorption of $\mathrm{Ce}_{0.8} \mathrm{Ca}_{0.2} \mathrm{O}_{1.8}$ and $\mathrm{K}_{0.81} \mathrm{Li}_{0.27} \mathrm{Ti}_{1.73} \mathrm{O}_{4}$ were ca. 400 and $330 \mathrm{~nm}$, respectively. The transparencies in the visible light region of $\mathrm{K}_{0.81} \mathrm{Li}_{0.27} \mathrm{Ti}_{1.73} \mathrm{O}_{4}$ coated with $\mathrm{Ce}_{0.8} \mathrm{Ca}_{0.2} \mathrm{O}_{1.8}$ and $\mathrm{K}_{0.8} \mathrm{Li}_{0.27} \mathrm{Ti}_{1.73} \mathrm{O}_{4}$ alone were slightly lower than that of $\mathrm{Ce}_{0.8} \mathrm{Ca}_{0.2} \mathrm{O}_{1.8}$, probably due to the scattering of visible light by large plate-like particles. In a previous paper ${ }^{12)}$ it was reported that the UV-shielding ability of $\mathrm{Ce}_{0.8} \mathrm{Ca}_{0.2} \mathrm{O}_{1.8}$ decreased by mixing mica because mica does not possess UV-shielding ability. In contrast, the UV shielding ability of $\mathrm{K}_{0.81} \mathrm{Li}_{0.27} \mathrm{Ti}_{1.73} \mathrm{O}_{4}$ coated with $\mathrm{Ce}_{0.8} \mathrm{Ca}_{0.2} \mathrm{O}_{1.8}$ was superior to that of $\mathrm{Ce}_{0.8} \mathrm{Ca}_{0.2} \mathrm{O}_{1.8}$ alone despite the decrease of cerium content although $\mathrm{K}_{0.81} \mathrm{Li}_{0.27} \mathrm{Ti}_{1.73} \mathrm{O}_{4}$ showed lower UVshielding ability than $\mathrm{Ce}_{0.8} \mathrm{Ca}_{0.2} \mathrm{O}_{1.8}$. It may be due to better 

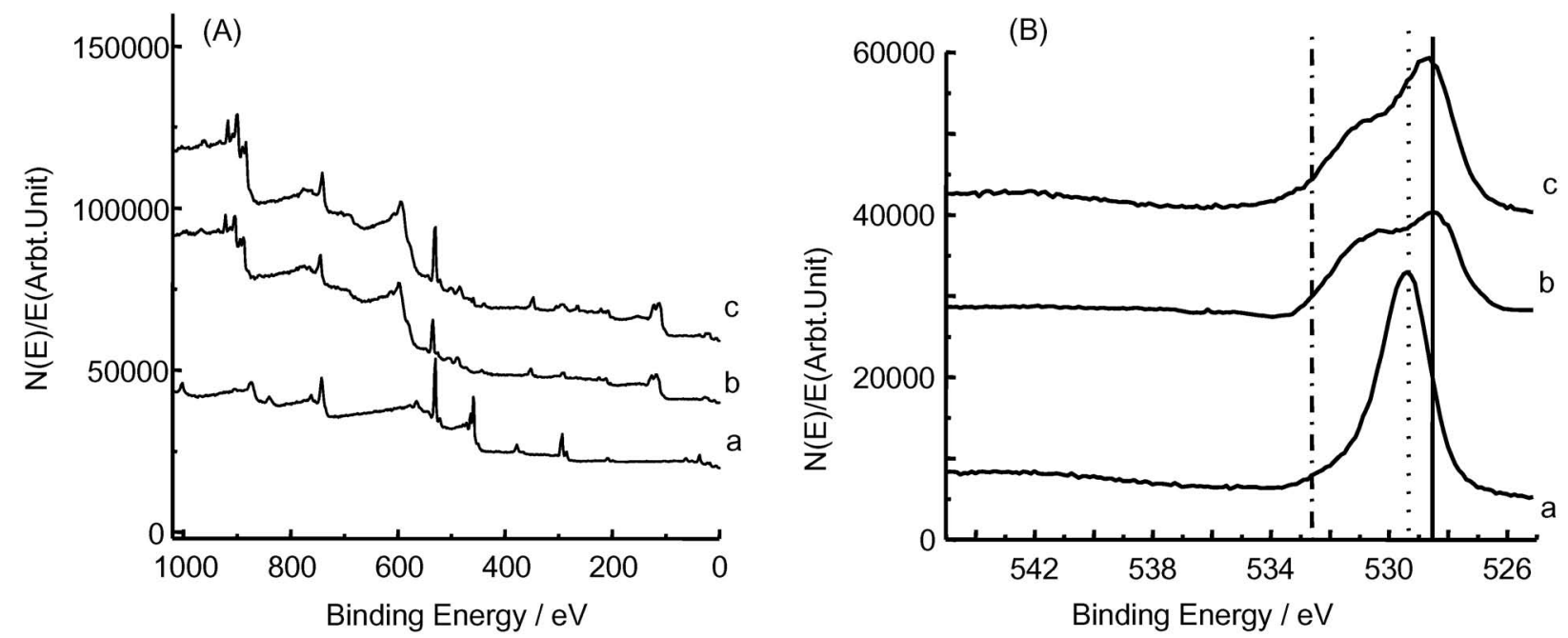

Fig. 7. (A) Entire XPS spectra and (B) XPS $\mathrm{O}_{1 \mathrm{~s}}$ core level spectra of (a) $\mathrm{K}_{0.81} \mathrm{Li}_{0.27} \mathrm{Ti}_{1.73} \mathrm{O}_{4}$, (b) $\mathrm{Ce}_{0.8} \mathrm{Ca}_{0.2} \mathrm{O}_{1.8}$ and (c) $\mathrm{K}_{0.81} \mathrm{Li}_{0.27} \mathrm{Ti}_{1.73} \mathrm{O}_{4}$ coated with 70 mass $\% \mathrm{Ce}_{0.8} \mathrm{Ca}_{0.2} \mathrm{O}_{1.8}$.

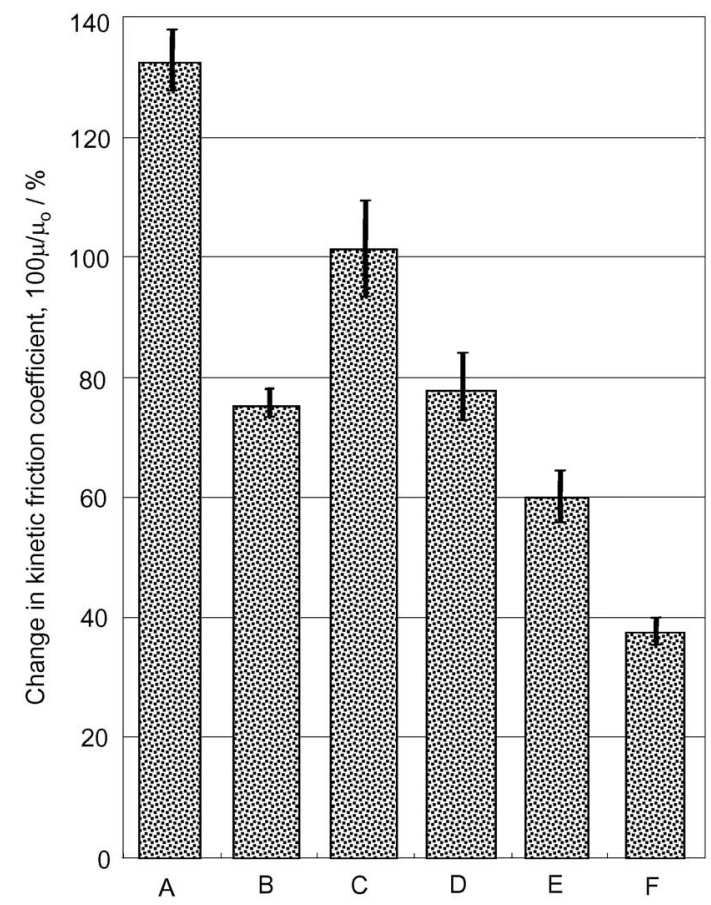

Fig. 8. Kinetic friction coefficient of the various samples. mo: Artificial leather without sample, $\mathrm{m}$ : Artificial leather applied the sample powder on. A: $\mathrm{TiO}_{2}$ (Ishihara Sangyo Co., TTO-55A), B: Talc coated with 50 mass\% $\mathrm{TiO}_{2}$ (Catalysts \& Chemicals Ind. Co, Coverleaf PC-2055T), C: $\quad \mathrm{Ce}_{0.8} \mathrm{Ca}_{0.2} \mathrm{O}_{1.8}, \quad \mathrm{D}: \mathrm{K}_{0.81} \mathrm{Li}_{0.27} \mathrm{Ti}_{1.73} \mathrm{O}_{4}$ coated with 50 mass\% $\mathrm{Ce}_{0.8} \mathrm{Ca}_{0.2} \mathrm{O}_{1.8}, \mathrm{E}: \mathrm{K}_{0.81} \mathrm{Li}_{0.27} \mathrm{Ti}_{1.73} \mathrm{O}_{4}, \mathrm{~F}$ : BN (Mizushima Ferroally Co., SHP-4).

distribution of $\mathrm{Ce}_{0.8} \mathrm{Ca}_{0.2} \mathrm{O}_{1.8}$ after coupling with plate-like $\mathrm{K}_{0.81} \mathrm{Li}_{0.27} \mathrm{Ti}_{1.73} \mathrm{O}_{4}$. These results excemplify the importance of coupling the $\mathrm{Ce}_{0.8} \mathrm{Ca}_{0.2} \mathrm{O}_{1.8}$ nanoparticles with plate-like materials to improve its UV-rays blocking properties.

Figure 10 shows the results of the oxidation catalytic activity evaluation by the Rancimat method for $\mathrm{K}_{0.81} \mathrm{Li}_{0.27} \mathrm{Ti}_{1.73} \mathrm{O}_{4}$ coated with 70 mass $\% \mathrm{Ce}_{0.8} \mathrm{Ca}_{0.2} \mathrm{O}_{1.8}$. It can be seen that the oxidation catalytic activity of $\mathrm{K}_{0.81} \mathrm{Li}_{0.27} \mathrm{Ti}_{1.73} \mathrm{O}_{4}$ coated with 70 mass $\% \mathrm{Ce}_{0.8} \mathrm{Ca}_{0.2} \mathrm{O}_{1.8}$ was much lower than $\mathrm{Ce}_{0.8} \mathrm{Ca}_{0.2} \mathrm{O}_{1.8}$

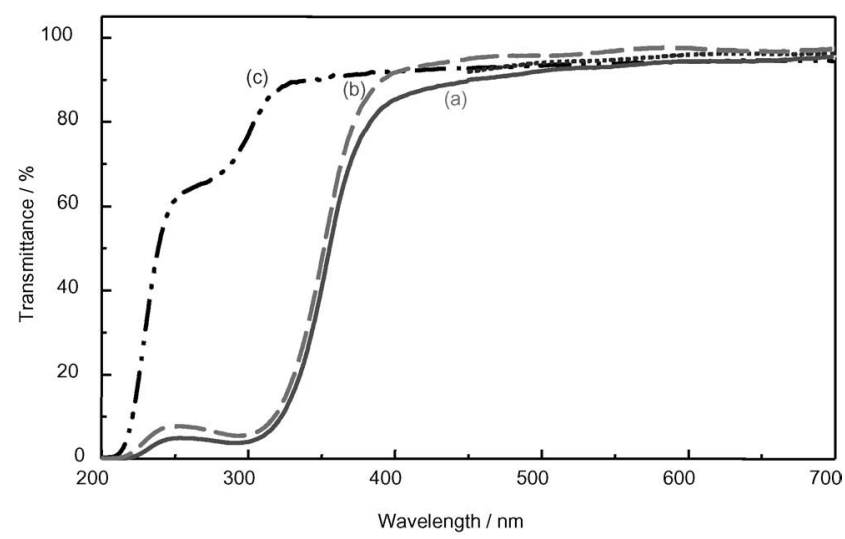

Fig. 9. UV-Vis transmittance spectra of thin films of (a) $\mathrm{K}_{0.81} \mathrm{Li}_{0.27}$ $\mathrm{Ti}_{1.73} \mathrm{O}_{4}$ coated with 70 mass $\% \mathrm{Ce}_{0.8} \mathrm{Ca}_{0.2} \mathrm{O}_{1.8}$, (b) $\mathrm{Ce}_{0.8} \mathrm{Ca}_{0.2} \mathrm{O}_{1.8}$, and (c) $\mathrm{K}_{0.81} \mathrm{Li}_{0.27} \mathrm{Ti}_{1.73} \mathrm{O}_{4}$.

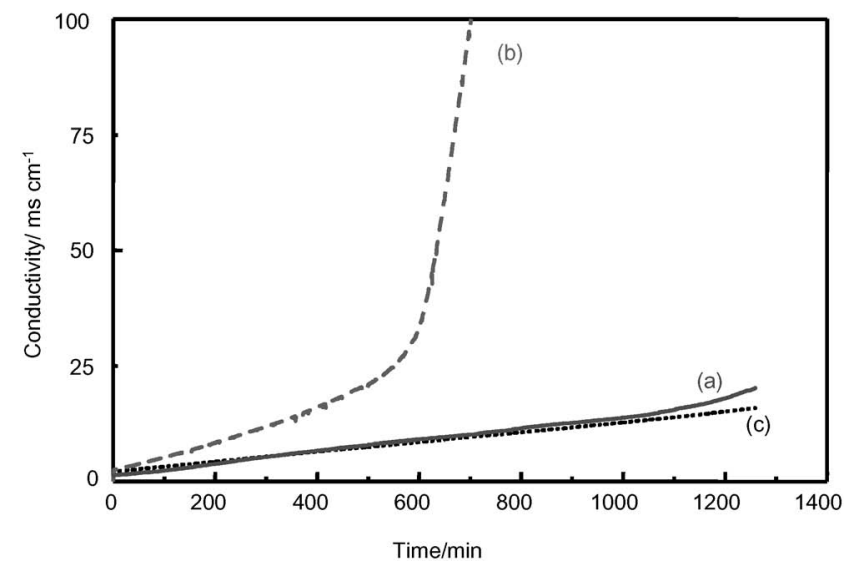

Fig. 10. Evaluation of the oxidation catalytic activity by Rancimat method at $120^{\circ} \mathrm{C}$. (a) $\mathrm{K}_{0.81} \mathrm{Li}_{0.27} \mathrm{Ti}_{1.73} \mathrm{O}_{4}$ coated with 70 mass $\%$ $\mathrm{Ce}_{0.8} \mathrm{Ca}_{0.2} \mathrm{O}_{1.8}$, (b) $\mathrm{Ce}_{0.8} \mathrm{Ca}_{0.2} \mathrm{O}_{1.8}$, (c) blank.

probably due to the decrease of reaction effective surface area of $\mathrm{Ce}_{0.8} \mathrm{Ca}_{0.2} \mathrm{O}_{1.8}$ by coupling it with plate-like $\mathrm{K}_{0.81} \mathrm{Li}_{0.27}$ 


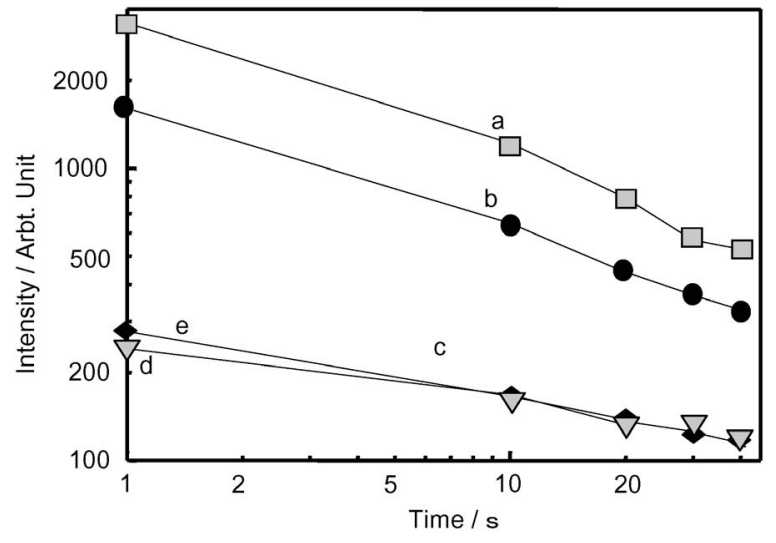

Fig. 11. Chemiluminescence caused by singlet oxygen determined by irradiating the sample powder with UV rays at room temperature. (a) $\mathrm{TiO}_{2}$ (Degussa, P25), (b) $\mathrm{ZnO}$ (Sumitomo Osaka Cement, $\mathrm{ZnO}-350$ ), (c) $\mathrm{Ce}_{0.8} \mathrm{Ca}_{0.2} \mathrm{O}_{1.8}$, (d) $\mathrm{K}_{0.81} \mathrm{Li}_{0.27} \mathrm{Ti}_{1.73} \mathrm{O}_{4}$ coated with 70 mass $\% \mathrm{Ce}_{0.8} \mathrm{Ca}_{0.2} \mathrm{O}_{1.8}$.

$\mathrm{Ti}_{1.73} \mathrm{O}_{4}$.

It is well-known that active oxygen species such as $\cdot \mathrm{O}_{2}^{-}$, $\cdot \mathrm{OOH}, \cdot \mathrm{OH}$ and ${ }^{1} \mathrm{O}_{2}$ (singlet oxygen) are formed by the band gap excitation of semiconductors in air and play an important role in photocatalytic reactions. Singlet oxygen has so-called dimole emission (3) and monomole emission (4). ${ }^{13)}$

$$
\begin{aligned}
& { }^{1} \mathrm{O}_{2}+{ }^{1} \mathrm{O}_{2} \rightarrow 2^{3} \mathrm{O}_{2}+\mathrm{h} v(634 \text { and } 703 \mathrm{~nm}) \\
& { }^{1} \mathrm{O}_{2} \rightarrow{ }^{3} \mathrm{O}_{2}+\mathrm{h} v(1270 \mathrm{~nm})
\end{aligned}
$$

By the chemiluminescence assay, it was indicated that the amounts of ${ }^{1} \mathrm{O}_{2}$ generation on the surface of $\mathrm{K}_{0.81} \mathrm{Li}_{0.27} \mathrm{Ti}_{1.73} \mathrm{O}_{4}$ coated with 70 mass $\% \mathrm{Ce}_{0.8} \mathrm{Ca}_{0.2} \mathrm{O}_{1.8}$ were similar to that on $\mathrm{Ce}_{0.8} \mathrm{Ca}_{0.2} \mathrm{O}_{1.8}$ and much lower than that on $\mathrm{ZnO}$ and $\mathrm{TiO}_{2}$ (Fig. 11). These results suggest that the photocatalytic activity of $\mathrm{K}_{0.81} \mathrm{Li}_{0.27} \mathrm{Ti}_{1.73} \mathrm{O}_{4}$ coated with 70 mass $\% \mathrm{Ce}_{0.8} \mathrm{Ca}_{0.2} \mathrm{O}_{1.8}$ is much lower than that of $\mathrm{ZnO}$ and $\mathrm{TiO}_{2}$ as $\mathrm{Ce}_{0.8} \mathrm{Ca}_{0.2} \mathrm{O}_{1.8}$ probably due to the large amount of oxygen defect in the lattice of ceria which is the great advantage of this material in terms of cosmetic application.

\section{Conclusions}

The UV shielding performance of $\mathrm{Ce}_{0.8} \mathrm{Ca}_{0.2} \mathrm{O}_{1.8}$ was enhanced by coupling with plate-like $\mathrm{K}_{0.81} \mathrm{Li}_{0.27} \mathrm{Ti}_{1.73} \mathrm{O}_{4}$ particles. $\mathrm{K}_{0.81} \mathrm{Li}_{0.27} \mathrm{Ti}_{1.73} \mathrm{O}_{4}$ coated with $\mathrm{Ce}_{0.8} \mathrm{Ca}_{0.2} \mathrm{O}_{1.8}$ shows superior comfort when applied to the skin and has better UV-shielding properties when compared with $\mathrm{Ce}_{0.8} \mathrm{Ca}_{0.2} \mathrm{O}_{1.8}$. Characterization of $\mathrm{K}_{0.81} \mathrm{Li}_{0.27} \mathrm{Ti}_{1.73} \mathrm{O}_{4}$ coated with $\mathrm{Ce}_{0.8} \mathrm{Ca}_{0.2}$ $\mathrm{O}_{1.8}$ by SEM, TEM and XPS indicates the coverage of platelike $\mathrm{K}_{0.81} \mathrm{Li}_{0.27} \mathrm{Ti}_{1.73} \mathrm{O}_{4}$ surface with $\mathrm{Ce}_{0.8} \mathrm{Ca}_{0.2} \mathrm{O}_{1.8}$ nanoparticles. The catalytic ability of $\mathrm{K}_{0.81} \mathrm{Li}_{0.27} \mathrm{Ti}_{1.73} \mathrm{O}_{4}$ coated with $\mathrm{Ce}_{0.8} \mathrm{Ca}_{0.2} \mathrm{O}_{1.8}$ for air oxidation of castor oil was lower than that of $\mathrm{Ce}_{0.8} \mathrm{Ca}_{0.2} \mathrm{O}_{1.8}$ nanoparticles.

Acknowledgment This research was partially supported by the Ministry of Education, Culture, Sports, Science and Technology, Scientific Research of Priority Areas "Panoscopic Assembling and High Ordered Functions for Rare Earth Materials," Special Education and Research Expenses on "Post-Silicon Materials and Devices Research Alliance" and the JSPS Asian Core Program "Interdisciplinary Science of Nanomaterials."

\section{References}

1) R. Cai, K. Hashimoto, K. Itoh, Y. Kubota and A. Fujita, Bull. Chem. Soc. Jpn., 64, 1268-1273 (1991).

2) T. C. Long, N. Saleh, R. D. Tilton, G. V. Lowry and B. Veronesi, Env. Sci. Technol., 40, 4346-4352 (2006).

3) S. Yabe and S. Momose, J. Soc. Cosmat. Chem. Jpn., 32, 372-378 (1998).

4) S. Yabe, M. Yamashita, S. Momose, K. Tahira, S. Yoshida, R. $\mathrm{Li}, \mathrm{S}$. Yin and T. Sato, Inter. J. Inorg. Mater., 3, 1003-1008 (2001).

5) S. Yabe, M. Yamashita, S. Momose, S. Yoshida, K. Hasegawa, S. Yin and T. Sato, J. Soc. Inorg. Mater. Japan, 8, 428-433 (2001).

6) S. Yabe and T. Sato, J. Solid State Chem., 171, 7-11 (2003).

7) T. Sato, T. Katakura, S. Yin, T. Fujimoto and S. Yabe, Soild State Ionics, 172, 377-382 (2004).

8) K. Domen, A. Kudo, M. Shibata, A. Tanaka, K. Maruya and T. Onishi, J. Chem. Soc., Chem. Commn., 1706-1707 (1986).

9) A. M. El-Toni, S. Yin and T. Sato, Mater. Lett., 60, 185-189 (2006).

10) T. Miyazawa, K. Fujimoto, M. Kinoshita and R. Usuki. J. Am. Oil Chem. Soc., 71, 343-345 (1994).

11) A. M. El-Toni, S. Yin and T. Sato, Appl. Surface Sci., 252, 5063-5070 (2006).

12) A. M. El-Toni, S. Yin and T. Sato, Adv. Sci. Technol., 45, 673-678 (2006).

13) J. R. Kanofsky, Chem.-Biol. Interact., 70, 1-28 (1989). 